\title{
Effect of Afghan Saffron (Crocus sativus L.) Aqueous Extract on Withdrawal Signs in Morphine-Dependent Rats
}

\author{
Elham Akbari', Kawsar Alami', Dawood Hossaini' ${ }^{1}$, Mohammad Latif Nazari', Mohammad Hossein Salehi' \\ Meysam Sajjadi ${ }^{1}$, Sayed Yousof Mousavi ${ }^{3, *}$
}

Elham Akbari' ${ }^{1}$ Kawsar Alami ${ }^{1}$, Dawood Hossaini' ${ }^{1}$, Mohammad Latif Nazari' ${ }^{\prime}$ Mohammad Hossein Salehi', Meysam Sajjadi', Sayed Yousof Mousavi ${ }^{3, *}$

'Research and Technology Center, Khatam Al-Nabieen University, Karte 4, 1st street, Kabul, AFGHANISTAN.

${ }^{2}$ Department of Biology, Kabul Medical

University, Ataturk avenue, Jamal Mena, 3rd District, Kabul, AFGHANISTAN.

${ }^{3}$ Department of Physiology, Khatam Al-

Nabieen university, Karte 4, 1st street, Kabul, AFGHANISTAN.

\section{Correspondence}

\section{Sayed Yousof Mousavi}

Department of Physiology, Khatam AlNabieen university, Karte 4, 1st street, Kabul, AFGHANISTAN

Phone no: +93(0)796850084;

E-mail: mousavi.knurtc@knu.edu.af

History

- Submission Date: 12-08-2020;

- Review completed: 17-09-2020;

- Accepted Date: 21-09-2020.

\section{DOI : 10.5530/pj.2020.12.234}

Article Available online

http://www.phcogj.com/v12/i6s

Copyright

(C) 2020 Phcogj.Com. This is an openaccess article distributed under the terms of the Creative Commons Attribution 4.0 International license.

\section{ABSTRACT}

Introduction: Opioid dependency, as a global problem is accompanied with serious personal, economic, social and hygienic disorders. Synthetic drugs beside their efficacies, have numerous adverse effects. As the medicinal plants have low costs and adverse effects, and they are also affective on different stages of dependency treatment, they attracted the attention of the researchers in the field of medicine. This study was aimed to investigate the effect of the aqueous extract of Afghan saffron on the withdrawal signs in morphine-dependent rats. Methods: Rats divided into 5 groups (1 Normal Saline, 1 Morphine, and 3 Extract groups). The rats that received morphine and extract became morphine-dependent by subcutaneous (s.c.) administration of morphine hydrochloride for 7 days $(2.5,2.5,5,10,20,40 \mathrm{mg} / \mathrm{kg}$ doses twice daily on $1 \mathrm{st}$ to 6 th days respectively, and a single dose of $50 \mathrm{mg} / \mathrm{kg}$ on 7 th day). The extract groups received 100, 150 and $200 \mathrm{mg} / \mathrm{kg}$ doses of the saffron aqueous extract by intraperitoneal (i.p.) administration simultaneously with morphine. Two hours after the administration of the last dose of morphine, Naloxone (3 mg/kg, i.p.) was injected and withdrawal signs were noted for 30 minutes. Results: The results showed that the administration of the saffron aqueous extract $(100,150$ and $200 \mathrm{mg} / \mathrm{kg})$ significantly decreased most of the withdrawal signs in morphine-dependent rats $(P<0.05)$. Conclusion: Afghan saffron aqueous extract can alleviate the withdrawal signs in morphine-dependent rats.

Key Words: Crocus, Morphine dependence, Withdrawal signs, Aqueous extract.

\section{INTRODUCTION}

There are some reports about the interaction between saffron and opioid system. ${ }^{1,2}$ Studies have shown that saffron and its constituents can alleviate morphine-induced behavioral disorders. Meanwhile, in different geographical regions, the saffron extract has been proven to reduce the withdrawal signs in morphine-dependent mice. $^{2}$ However, despite the undeniable effect of geographical and climatic conditions on the quality of the plant's impact, ${ }^{3}$ there is no evidence of the effect of Afghan native saffron on morphine withdrawal signs. This study aimed to evaluate the effect of aqueous extract of Afghan native saffron on withdrawal signs in morphine-dependent rats, using the behavioral method.

Opioid dependency as a global problem, is accompanied by serious personal, economic, social and hygienic disorders. ${ }^{4}$ There are multiple neurotransmitter systems, such as dopaminergic, GABAergic, cholinergic, glutamatergic, serotonergic, orexinergic and noradrenergic systems that play an important role in the development of opioid dependency and withdrawal signs. $^{5-16}$ There is a close relationship between major neurotransmitter systems in the brain, thus any changes in one of these systems can alter other systems.

Medicinal plants have attracted a wide range of attention in the treatment of drug dependency, because of their fewer side effects and costs than synthetic drugs. ${ }^{17-19}$ One of the useful and wellknown medicinal plants is saffron (Crocus sativus L.). This grassy and perennial plant, which is known as the king of the world's medicines, is native in the Asian southwest countries. ${ }^{20-22}$ Today, saffron is mainly found in Afghanistan, Iran, Italy, India and some other countries. ${ }^{22,23}$ Saffron contains three key components, known as crocin, picrocrocin, and safranal. ${ }^{23}$

Some experiments which are done on the effect of saffron extract and its constituents on different aspects of morphine dependency in different geographical regions have shown that the extract of saffron, as well as its crocin constituent, are effective in the prevention of withdrawal signs in morphinedependent mice. ${ }^{2}$

However, because the previous studies have shown that climate changes, geographical situations, and many other factors, make a great impact on the composition of a plant and thereby on its biological activity, ${ }^{3,24}$ this question comes up that Afghan native saffron despite its impression by climate and geographical conditions, what effects will it have on withdrawal signs in morphine-dependent rats. This study wants to focus on this question, so, is going to investigate the effect of aqueous extract of Afghan saffron on morphine-dependent rats, using the behavioral method of counting the naloxoneinduced withdrawal signs. 


\section{MATERIALS AND METHODS}

\section{Plant material and extraction}

Fresh Crocus sativus L. stigmas were collected from Khaja Sarbar, Herat province of Afghanistan. Stigmas were dried in the laboratory environment, and then powdered. $4 \mathrm{~g}$ of stigma powder was macerated in $500 \mathrm{ml}$ of distilled water and kept at room temperature for 72 hours. The supernatant was collected by centrifuging and filtered from filter paper. The solvent was evaporated at $50^{\circ} \mathrm{C}$ using an oven. As a result, the aqueous extract of saffron was obtained..$^{2,25}$

\section{Animals}

Thirty adult Sprague-Dawley male rats weighing between 150 and 200 g, randomly selected from Khatam Al-Nabieen University Research and Technology Center (KNURTC), were housed in Plexy-glass cages with free access to food and water. Animals were kept under stable room temperature $\left(23 \pm 2^{\circ} \mathrm{C}\right)$ and a 12 hours light/dark cycle (the light period started at 7 a.m.). The experimental protocol approved by the ethic research board of Khatam Al-Nabieen University and were conducted following the ethical guidelines set by the $8^{\text {th }}$ edition of National Institute of Health (NIH) guide for the care and use of laboratory animals. Rats were carefully handled to minimize unwanted stress during housing and experiments.

\section{Experimental groups}

The rats were randomly divided into 5 groups $(\mathrm{n}=6)$. Group 1, salinetreated rats; Group 2, morphine-treated rats received naloxone to evaluate morphine withdrawal signs; Group 3-5, rats received saffron extract $(100,150$, and $200 \mathrm{mg} / \mathrm{kg}$ doses) by i.p. administration simultaneously with morphine. They also received naloxone 2 hours after the last morphine administration.

\section{Induction of morphine dependency}

To induce morphine dependency, rats received a subcutaneous injection of morphine hydrochloride for 7 days. The doses of morphine were 2.5, $2.5,5,10,20$ and $40 \mathrm{mg} / \mathrm{kg}$ twice daily on $1^{\text {st }}$ days to $6^{\text {th }}$ day respectively and a single dose of $50 \mathrm{mg} / \mathrm{kg}$ on 7 th day. ${ }^{26}$

\section{Induction and monitoring of morphine-withdrawal signs}

Morphine withdrawal signs were induced by injection of Naloxone $(3 \mathrm{mg} / \mathrm{kg}$, i.p.) 2 hours after the last morphine injection. Thereafter, six distinct withdrawal signs (jumping, rearing, paw tremor, teeth chattering, penis licking and chewing) were monitored in a glass cylinder during a $30 \mathrm{~min}$ period.

\section{Statistical analysis}

The statistical data analysis was performed using Graph Pad Prism 6.07 software. The morphine withdrawal signs recorded in different experimental groups of animals were statistically analyzed by Kruskal Wallis test when counts were not normally distributed. Multiple comparisons performed by the One-Way ANOVA test. The difference amongst means was considered statistically significant if the $\mathrm{P}<0.05$. The results are expressed as mean \pm SEM.

\section{RESULTS}

In this study, morphine-treated rats showed morphine withdrawal signs following the intraperitoneal injection of naloxone hydrochloride $(3 \mathrm{mg} / \mathrm{kg})$. There was a significant difference in the number of jumping, rearing, teeth chattering, paw tremor, penis licking and chewing among control and morphine group. Also, there was a significant reduction in the number of rearing, teeth chattering and chewing in each 100, 150 and $200 \mathrm{mg} / \mathrm{kg}$ extract groups as compared with the morphine group. The number of jumping and paw tremors was statistically decreased in 100 and $150 \mathrm{mg} / \mathrm{kg}$ extract group than the morphine group. However, the number of penis licking was significantly decreased only in the 150 $\mathrm{mg} / \mathrm{kg}$ extract group (Table 1).

\section{DISCUSSION}

In this study, the effect of aqueous extract of afghan saffron on morphinedependent rats was evaluated. First, the results showed that the number of some distinct withdrawal signs including jumping, rearing, teeth chattering, paw tremor, penis licking, and chewing was significantly increased in morphine group than the control group, it means the injection of morphine hydrochloride developed morphine dependency in the morphine received rats. Also, the results indicated that saffron aqueous extract significantly decreased the various withdrawal signs in morphine-dependent rats. The $100 \mathrm{mg} / \mathrm{kg}$ dose of the saffron extract could decrease the number of rearing, teeth chattering, jumping, paw tremor and chewing in morphine-dependent rats. But the $200 \mathrm{mg} / \mathrm{kg}$ dose only reduced the number of rearing, teeth chattering and chewing. However, the $150 \mathrm{mg} / \mathrm{kg}$ dose of the saffron extract could decrease all of the signs which are observed in this study. Thus, we can conclude that the effect of Afghan saffron on the number of withdrawal signs is better by low doses, especially by $150 \mathrm{mg} / \mathrm{kg}$.

As the previous studies have shown that saffron aqueous extract and its crocin constituent decreased the withdrawal signs, which confirm the results of our study. ${ }^{2}$ However, there is a difference between the effective dose of native saffron from Afghanistan and Iran. The aqueous extract of Iranian saffron decreased the number of jumping in mice by doses 40,160 and $320 \mathrm{mg} / \mathrm{kg}$, and this effect was enhanced dose-dependently. ${ }^{2}$ But the aqueous extract of Afghan saffron decreased the number of jumping by 100 and $150 \mathrm{mg} / \mathrm{kg}$ dose and this effect was not enhanced dose-dependently, so the $200 \mathrm{mg} / \mathrm{kg}$ dose of Afghan saffron extract could not decrease the number of jumping in morphine-dependent rats. This difference seems to be due to the different constituents of Afghan saffron. Various studies have shown that many factors such as climate and especially geographical situations can affect the biological activity of plants, and the biological activity greatly depends on major active components. ${ }^{3,24,27}$ Some of these factors may lead to the absence of active constituent(s) of a plant collected from different geographical regions. ${ }^{28}$ For example, some studies on the hypoglycemic effects of Peganum harmala extract on diabetic rats, have shown that the effect

Table 1: Effect of Afghan Saffron aqueous extract on naloxone-induced withdrawal signs.

\begin{tabular}{|c|c|c|c|c|c|c|}
\hline \multirow{2}{*}{ Groups } & \multicolumn{6}{|c|}{ Signs } \\
\hline & Jumping & Rearing & Teeth chattering & Paw tremor & Penis licking & Chewing \\
\hline Control & $0.00 \pm 0.00^{* *}$ & $7.83 \pm 0.48^{* * *}$ & $0.00 \pm 0.00^{* \star *}$ & $0.83 \pm 0.17^{* *}$ & $0.00 \pm 0.00^{* *}$ & $16.33 \pm 0.84^{* * x+}$ \\
\hline Morphine & $2.67 \pm 0.61$ & $20.33 \pm 2.52$ & $4.67 \pm 0.99$ & $8.83 \pm 2.26$ & $1.17 \pm 0.31$ & $42.00 \pm 8.15$ \\
\hline $100 \mathrm{mg} / \mathrm{Kg}$ Extract & $0.33 \pm 0.33^{*}$ & $3.17 \pm 0.70^{*+x+x}$ & $0.50 \pm 0.34^{* *}$ & $1.67 \pm 0.80^{*}$ & $0.33 \pm 0.33$ & $19.67 \pm 2.09^{* *}$ \\
\hline $150 \mathrm{mg} / \mathrm{Kg}$ Extract & $0.33 \pm 0.21^{*}$ & $5.33 \pm 0.92^{* * * *+}$ & $0.33 \pm 0.21^{* *}$ & $1.50 \pm 0.76^{*}$ & $0.17 \pm 0.17^{*}$ & $22.00 \pm 2.93^{* *}$ \\
\hline $200 \mathrm{mg} / \mathrm{Kg}$ Extract & $1.83 \pm 0.83$ & $7.17 \pm 3.06^{* * *}$ & $0.67 \pm 0.33^{*}$ & $4.33 \pm 1.08$ & $0.33 \pm 0.21$ & $24.33 \pm 1.48^{*}$ \\
\hline
\end{tabular}

Data were expressed as mean \pm SEM. ${ }^{*}: \mathrm{p}<0.05,{ }^{* *}: \mathrm{p}<0.01,{ }^{* * *}: \mathrm{p}<0.001,{ }^{* * * *}: \mathrm{p}<0.0001$. 
of that extract on blood glucose levels is different from the results of similar studies. It was hypothesized that such differences may be resulted from different combinations, due to different regions. ${ }^{29}$ Therefore, the difference between the biological activity of Afghan saffron and Iranian one may be related to different constituents and chemical composition caused by the effect of climate and especially geographical situations of these regions. As there is not a study about the number of chemical compositions of Afghan saffron, we cannot say that this difference in biological activity exactly related to the high/low amount of the constituent(s). Because a previous study has shown that crocin and safranal constituents are the key components of saffron and those can alter the morphine withdrawal signs significantly, ${ }^{2}$ presumably, the different effects of Afghan saffron on withdrawal signs are related to the amount of these constituents.

It has been shown that sedative compounds such as benzodiazepines beside their anxiolytic and anti-convulsant effects, can alleviate the naloxone-induced morphine withdrawal signs in animals and humans. ${ }^{17,30}$ These drugs exert their effects through the facilitation of the action of GABA in GABA-A receptors. GABA-A receptors are ligand-gated chloride channels. ${ }^{30,31}$ Benzodiazepines bind to GABA-A receptors and modify GABA-induced neuronal membrane conductance for chloride ions. As a result, membrane hyperpolarization rise in and reduces neuronal excitability. Consequently, drugs exert their sedative effects through this mechanism. ${ }^{32,33}$ Also, benzodiazepines such as diazepam increase the frequency of chloride channels opening in GABA-A receptors and thereby increases the GABA actions. ${ }^{33}$

Also, experiments showed that besides benzodiazepines, other compounds such as flavonoids can attach to binding sites in GABA-A/ benzodiazepine receptors complex. Regional heterogeneity of GABA-A/benzodiazepine receptors complex causes a multiplicity of pharmacologic characteristics for benzodiazepine binding sites ligands. Thus, besides benzodiazepines, other compounds can bind to those binding sites and exert their effects. ${ }^{32,33}$

The previous study showed that saffron aqueous extract has many effects, including anti-anxiety, sedative, decreasing the locomotion activity, muscle-relaxant and prolonging the sleeping time. These effects of the saffron aqueous extract are similar to diazepam. Thus it may be due to the facilitation of some inhibitory systems such as the GABAergic system. Aqueous extract of saffron probably exerts its effects through GABA-A/ benzodiazepine receptors complex, because of the heterogeneity of benzodiazepine binding sites. ${ }^{34}$ Similarly, in a review article about the effect of saffron and its constituents on the nervous system, concluded that the decrease of withdrawal signs due to saffron administration may result from interactions between GABAergic system, saffron and opioid system. ${ }^{35}$ As saffron aqueous extract has anxiolytic, sedative and musclerelaxant effects, and sedative compounds can alleviate the naloxoneinduced withdrawal signs, ${ }^{17,34}$ the saffron aqueous extract may probably reduce the withdrawal signs in morphine-dependent rats, because of its sedative effects and facilitation of GABA actions through GABA-A/ benzodiazepine receptors complex. Saffron extract may have interacted with benzodiazepine binding sites on GABA-A receptors and induced membrane hyperpolarization through the facilitation of GABA actions and increasing the frequency of chloride channels opening in GABA-A receptors, thereby exerts its anti-anxiety, sedative and muscle relaxant effects. As a result, it could alleviate the withdrawal signs in morphinedependent rats.

Also, electrophysiological studies of rat's brain slices shown that dopamine may involve in the modulation of norepinephrine release in the NAcc by an effect on dopamine receptors. ${ }^{36}$ The NAcc received dopaminergic innervation from VTA. ${ }^{37}$ Also, the shell portion of NAcc receives a dense norepinephrine-containing projection that is originating primarily from nucleus tractus solitarius. ${ }^{36,38}$ The Dopamine receptors that modulate the release of norepinephrine, are presumably localized on the nerve terminals of noradrenergic neurons, which are originating from the nucleus tractus solitarius. ${ }^{38}$ Therefore, it is possible that dopamine can indirectly have influences on norepinephrine release from NAcc through modulation of excitatory or inhibitory neurotransmission. Experiments have shown that norepinephrine release stimulated by activation of the $\mathrm{D} 1$ receptor and inhibited by activation of the $\mathrm{D} 2$ receptor. For this reason, the relation between noradrenergic and dopaminergic systems may involve in opioids withdrawal signs. As shown the injection of D2 receptor agonists in the shell portion of NAcc inhibits naloxone-induced withdrawal signs, whereas injection of D1 receptor agonists aggregate. Because the increased norepinephrine activity is accompanied by the opioids withdrawal signs, the effect of dopaminergic drugs on opioids withdrawal signs may result from modulation of norepinephrine release. $^{36}$

As previous studies have shown that aqueous extract of saffron can increase the dopamine level in the brain. ${ }^{39}$ Thus, a high level of dopamine in NAcc, resulting from the effect of saffron extract, can affect the release of norepinephrine. Because dopamine release from NAcc preferably acts on D2 receptors having a different location in nerve terminals, ${ }^{36}$ dopamine probably decreases the norepinephrine release through D2 receptors, thereby reducing the withdrawal signs.

In addition, many studies have shown that inflammatory processes and oxidative stress are greatly aggregated during morphine withdrawal. Also, various medicinal plants decrease the withdrawal signs, because of their anti-inflammatory and anti-oxidative properties. ${ }^{17,40}$ As it has been shown that saffron extract and its constituents have antiinflammatory and anti-oxidative properties. ${ }^{41-43}$ Therefore, probably the effect of saffron aqueous extract on the reduction of withdrawal signs in morphine-dependent rats also can be due to the effect of saffron extract and its constituents on inflammatory processes and oxidative stress.

\section{CONCLUSION}

In summary, one can conclude that aqueous extract of Afghan saffron reduces the withdrawal signs in morphine-dependent rats. The difference between an effective dose of Afghan saffron and Iranian one may be due to different constituent(s) of Afghan saffron and/or amount of them.

\section{ACKNOWLEDGEMENTS}

This work is supported by the research and technology center of Khatam Al-Nabieen University (KNURTC) Kabul, Afghanistan. We thank all officials for their valuable support for providing the equipment and facilities for this study.

\section{REFERENCES}

1. Yaribeygi H, Sahraei H, Mohammadi AR, Meftahi GH. Saffron (Crocus sativus L.) and morphine dependence: A systematic review article. Am J Biol Life Sci. 2014;2(2):41-5

2. Hosseinzadeh $H$, Jahanian Z. Effect of Crocus sativus L. (saffron) stigma and its constituents, crocin, and safranal, on morphine withdrawal syndrome in mice. Phytotherapy Research: An International Journal Devoted to Pharmacological and Toxicological Evaluation of Natural Product Derivatives. 2010;24(5):726-30. https://doi.org/10.1002/ptr.3011

3. Astaf'eva OV, Sukhenko LT. Comparative analysis of antibacterial properties and chemical composition of Glycyrrhiza glabra L. from Astrakhan region (Russia) and Calabria region (Italy). Bull Exp Biol Med. 2014;156(6):829-32. https://doi org/10.1007/s10517-014-2462-8

4. Motaghinejad M, Fatima S, Banifazl S, Bangash MY, Karimian M. Study of the effects of controlled morphine administration for treatment of anxiety, depression and cognition impairment in morphine-addicted rats. Adv Biomed Res. 2016;5:178. http://doi.org/10.4103/2277-9175.188491

5. Neugebauer NM, Einstein EB, Lopez MB, McClure-Belgey TD, Mineur YS Picciotto MR. Morphine dependence and withdrawal induced changes in cholinergic signaling. Pharmacol Biochemist Behav. 2013;109:77-83. https://doi. org/10.1016/j.pbb.2013.04.015 
6. Rockhold RW, Liu N, Coleman D, Commiskey S, Shook J, Ho K. The nucleus paragigantocellularis and opioid withdrawal-like behavior. J Biomed Sci. 2000;7(3):270-6. https://doi.org/10.1007/BF02255476

7. Lelevich SV, Lelevich VV, Novokshonov AA. Neurotransmitter mechanisms of morphine withdrawal syndrome. Bull Exp Biol Med. 2009;148(2):184. https:// doi.org/10.1007/s10517-009-0672-2

8. Mousavi Y, Azizi H, Mirnajafi-Zadeh J, Javan M, Semnanian S. Blockade of orexin type-1 receptors in locus coeruleus nucleus attenuates the development of morphine dependency in rats. Neurosci lett. 2014;578:90-4. https://doi. org/10.1016/j.neulet.2014.06.038

9. Fakhari M, Azizi H, Semnanian S. Central antagonism of orexin type-1 receptors attenuates the development of morphine dependence in rat locus coeruleus neurons. Neuroscience. 2017;363:1-0. https://doi.org/10.1016/j. neuroscience.2017.08.054

10. Abdollahi H, Ghaemi-Jandabi M, Azizi H, Semnanian S. The role of orexin type1 receptors in the development of morphine tolerance in locus coeruleus neurons: An electrophysiological perspective. Brain Res. 2016;1646:91-7. https://doi.org/10.1016/j.brainres.2016.05.043

11. Diaz SL, Kemmling AK, Balerio GN. Baclofen reestablishes striatal and cortical dopamine concentrations during naloxone-precipitated withdrawal. Neurochemist int. 2003;42(4):293-8. https://doi.org/10.1016/S01970186(02)00102-X

12. Vihavainen T, Relander TR, Leiviskä R, Airavaara M, Tuominen RK, Ahtee L, et al. Chronic nicotine modifies the effects of morphine on extracellular striatal dopamine and ventral tegmental GABA. J Neurochemist. 2008;107(3):844-54. https://doi.org/10.1111/j.1471-4159.2008.05676.x

13. Ghaemi-Jandabi M, Azizi $H$, Ahmadi-Soleimani SM, Semnanian S. Intracoerulear microinjection of orexin-A induces morphine withdrawal-like signs in rats. Brain Res Bulletin. 2017;130:107-11. https://doi.org/10.1016/j.brainresbull.2017.01.010

14. Kaeidi A, Azizi H, Javan M, Soleimani SM, Fathollahi Y, Semnanian S. Direct facilitatory role of paragigantocellularis neurons in opiate withdrawal-induced hyperactivity of rat locus coeruleus neurons: an in vitro study. PloS One. 2015;10(7). https://doi.org/10.1371/journal.pone.0134873

15. Ahmadi-Soleimani SM, Ghaemi-Jandabi M, Azizi H, Semnanian S. Orexin type 1 receptor antagonism in Lateral Paragigantocellularis nucleus attenuates naloxone precipitated morphine withdrawal symptoms in rats. Neurosci Lett. 2014;558:62-6. https://doi.org/10.1016/j.neulet.2013.10.064

16. Ahmadi-Soleimani SM, Azizi H, Gompf HS, Semnanian S. Role of orexin type1 receptors in paragiganto-coerulear modulation of opioid withdrawal and tolerance: a site specific focus. Neuropharmacology. 2017;126:25-37. https:// doi.org/10.1016/j.neuropharm.2017.08.024

17. Ebrahimie M, Bahmani M, Shirzad H, Rafieian-Kopaei M, Saki K. A review study on the effect of Iranian herbal medicines on opioid withdrawal syndrome. J Evid Based Complement Alternat Med. 2015;20(4):302-9. https://doi. org/10.1177/2156587215577896

18. Behere RV, Muralidharan K, Benegal V. Complementary and alternative medicine in the treatment of substance use disorders-a review of the evidence. Drug Alcohol Rev. 2009;28(3):292-300. https://doi.org/10.1111/j.14653362.2009.00028.x

19. Shi J, Liu YL, Fang YX, Xu GZ, Zhai HF, Lu L. Traditional Chinese medicine in treatment of opiate addiction. Acta Pharmacol Sin. 2006;27(10):1303. https:// doi.org/10.1111/j.1745-7254.2006.00431.x

20. Moshiri M, Vahabzadeh M, Hosseinzadeh $H$. Clinical applications of saffron (Crocus sativus) and its constituents: a review. Drug Res. 2015;65(06):287-95. http://eprints.mums.ac.ir/id/eprint/18993

21. Cusano E, Consonni R, Petrakis EA, Astraka K, Cagliani LR, Polissiou MG. Integrated analytical methodology to investigate bioactive compounds in Crocus sativus L. flowers. Phytochem Anal. 2018;29(5):476-86. https://doi. org/10.1002/pca.2753

22. Dar RA, Shahnawaz M, Malik SB, Sangale MK, Ade AB, Qazi PH. Cultivation, distribution, taxonomy, chemical composition and medical importance of Crocus sativus. J Phytopharmacol. 2017;6(6):356-8.

23. Baba SA, Malik AH, Wani ZA, Mohiuddin T, Shah Z, Abbas N, et al. Phytochemical analysis and antioxidant activity of different tissue types of Crocus sativus and oxidative stress alleviating potential of saffron extract in plants, bacteria, and yeast. S Afr J Bot. 2015;99:80-7. https://doi.org/10.1016/j.sajb.2015.03.194

24. Zhang X, Zhao Y, Guo L, Qiu Z, Huang L, Qu X. Differences in chemical constituents of Artemisia annua $L$ from different geographical regions in China. PLoS One. 2017;12(9):e0183047. https://doi.org/10.1371/journal.pone.0183047
25. Khorasani G, Hosseinimehr SJ, Zamani P, Ghasemi M, Ahmadi A. The effect of saffron (Crocus sativus) extract for healing of second-degree burn wounds in rats. Keio J Med. 2008;57(4):190-5. https://doi.org/10.2302/kjm.57.190

26. Gomaa A, Hashem T, Mohamed M, Ashry E. Matricaria chamomilla extract inhibits both development of morphine dependence and expression of abstinence syndrome in rats. J Pharmacol sci. 2003;92(1):50-5. https://doi. org/10.1254/S1347-8613(19)32695-7

27. Liu $Y$, Chen $P$, Zhou M, Wang T, Fang $S$, Shang $X$, et al. Geographic variation in the chemical composition and antioxidant properties of phenolic compounds from Cyclocarya paliurus (Batal) Iljinskaja leaves. Molecules. 2018;23(10):2440. https://doi.org/10.3390/molecules23102440

28. Banerjee SK, Bonde CG. Total phenolic content and antioxidant activity of extracts of Bridelia retusa Spreng Bark: Impact of dielectric constant and geographical location. J Med Plant Res. 2011;5(5):817-22. https://doi. org/10.5897/JMPR.9001249

29. Porbarkhordari E, Foladsaz K, Hoseini SH, Danafar H, Kheiri Manjili HR Ramazani A. The hypoglycemic effects of an ethanol extract of peganum harmala in streptozotocin-induced diabetic rats. Iran J Pharm Sci. 2014;10(3):4754. http://doi.org/ 10.22034/IJPS.2014.15246

30. Suzuki T, Tsuda M, Narita M, Funada M, Mizoguchi H, Misawa M. Diazepam pretreatment suppresses morphine withdrawal signs in the mouse. Life Sci. 1995;58(4):349-57. https://doi.org/10.1016/0024-3205(95)02294-5

31. Richter L, De Graaf C, Sieghart W, Varagic Z, Mörzinger M, De Esch IJ, et al. Diazepam-bound GABA A receptor models identify new benzodiazepine binding-site ligands. Nat Chem Biol. 2012;8(5):455. https://doi.org/10.1038/ nchembio.917

32. Marder M, Estiú G, Blanch LB, Viola H, Wasowski C, Medina JH, et al. Molecular modeling and QSAR analysis of the interaction of flavone derivatives with the benzodiazepine binding site of the GABAA receptor complex. Bioorg Med chem. 2001;9(2):323-5. https://doi.org/10.1016/S0968-0896(00)00250-9

33. Ai J, Dekermendijan K, Wang X, Nielsen M, Witt MR. 6-Methylflavone, a benzodiazepine receptor ligand with antagonistic properties on rat brain and human recombinant GABAA receptors in vitro. Drug Dev Res. 1997:41(2):99106. DDR7>3.0.CO;2-M https://doi.org/10.1002/(SICI)1098-2299(199706)41:2<99::AID-

34. Hosseinzadeh $\mathrm{H}$, Noraei NB. Anxiolytic and hypnotic effect of Crocus sativus aqueous extract and its constituents, crocin and safranal, in mice. Phytotherapy research: An International Journal Devoted to Pharmacological and Toxicological Evaluation of Natural Product Derivatives. 2009;23(6):768-74. https://doi. org/10.1002/ptr.2597

35. Khazdair MR, Boskabady MH, Hosseini M, Rezaee R, Tsatsakis AM. The effects of Crocus sativus (saffron) and its constituents on nervous system: A review. Avicenna J Phytomed. 2015;5(5):376.

36. Vanderschuren LJ, Wardeh G, De Vries TJ, Mulder AH, Schoffelmeer AN Opposing role of dopamine D1 and D2 receptors in modulation of rat nucleus accumbens noradrenaline release. J Neurosci. 1999;19(10):4123-31. https://doi. org/10.1523/JNEUROSCI.19-10-04123.1999

37. Goto $Y$, Grace AA. Dopamine-dependent interactions between limbic and prefrontal cortical plasticity in the nucleus accumbens: disruption by cocaine sensitization. Neuron. 2005;47(2):255-66. https://doi.org/10.1016/j. neuron.2005.06.017

38. Delfs JM, Zhu Y, Druhan JP, Aston-Jones GS. Origin of noradrenergic afferents to the shell subregion of the nucleus accumbens: anterograde and retrograde tract-tracing studies in the rat. Brain Res. 1998;806(2):127-40. https://doi. org/10.1016/S0006-8993(98)00672-6

39. Ettehadi H, Mojabi SN, Ranjbaran M, Shams J, Sahraei H, Hedayati M, et al Aqueous extract of saffron (Crocus sativus) increases brain dopamine and glutamate concentrations in rats. J Behav Brain Sci. 2013;3:315-9. http://doi. org/10.4236/jbbs.2013.33031

40. Guglielmo G, Kallupi M, Scuppa G, Stopponi S, Demopulos G, Gaitanaris G, et al. Analgesic tolerance to morphine is regulated by PPAR $\gamma$. Br J Pharmacol. 2014;171(23):5407-16. https://doi.org/10.1111/bph.12851

41. Samarghandian S, Azimi-Nezhad M, Farkhondeh T. Immunomodulatory and antioxidant effects of saffron aqueous extract (Crocus sativus L.) on streptozotocin-induced diabetes in rats. Indian Heart J. 2017;69(2):151-9. https://doi.org/10.1016/j.ihj.2016.09.008

42. Boskabady $\mathrm{MH}$, Farkhondeh T. Antiinflammatory, antioxidant, and immunomodulatory effects of Crocus sativus L. and its main constituents. Phytother Res. 2016;30(7):1072-94. https://doi.org/10.1002/ptr.5622

43. Hosseinzadeh $\mathrm{H}$, Younesi HM. Antinociceptive and anti-inflammatory effects of Crocus sativus L. stigma and petal extracts in mice. BMC pharmacol. 2002;2(1):7. https://doi.org/10.1186/1471-2210-2-7 


\section{GRAPHICAL ABSTRACT}

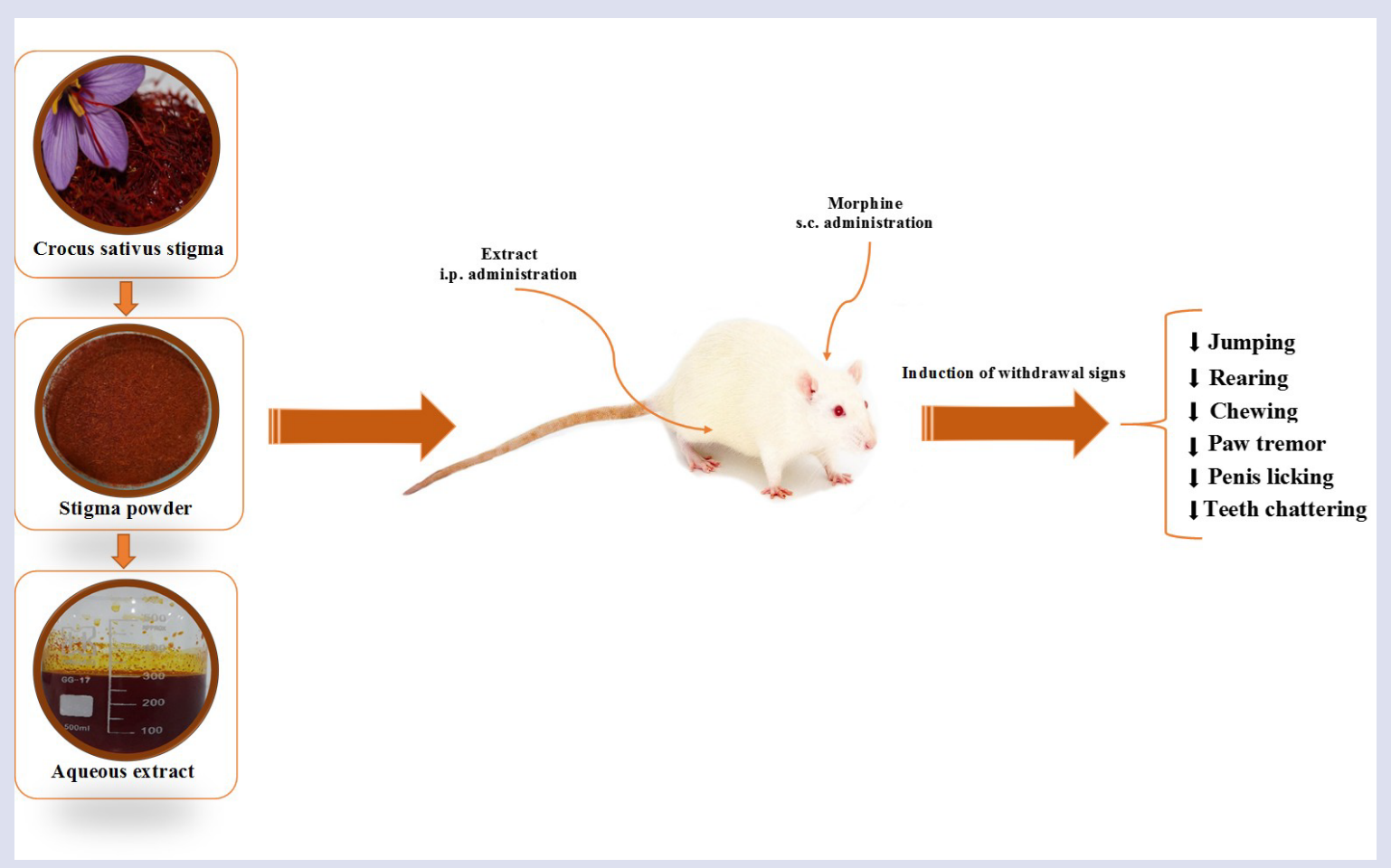

\section{ABOUT AUTHORS}

- Elham Akbari: Is a student in the medical laboratory technology faculty of Khatam Al-Nabieen University. She worked as a researcher in the Research and Technology Center of Khatam Al-Nabieen University.

- Kawsar Alami: Is a student in the medical faculty of Khatam Al-Nabieen University. She worked as a researcher and lecturer in the Research and Technology Center of Khatam Al-Nabieen University. She has researches mainly focused on the physiological and pharmacological aspects of medicinal plants. She has experience in the methods of learning and memory studies.

- Dawood Hossaini: Is a student in the medical laboratory technology faculty of Khatam Al-Nabieen University. He worked as a researcher in the Research and Technology Center of Khatam Al-Nabieen University.

- Mohammad Latif Nazari: Is a Master of Pharmacology and positioned as the head of the faculty of medical sciences in Khatam AlNabieen University. He has researches focused on the physiological and pharmacological aspects of medicinal plants.

- Mohammad Hussein Salehi: Is a Ph.D. of biology and a lecturer in the department of biology, Kabul University of medical sciences. He has worked on various topics such as mitochondrial diseases, biomarkers of mitochondrial diseases and biochemical and physiological issues in humans and rats. His research interests include working on DNA, RNA, PCR, paternity test, and research on biochemical characteristics.

- Meysam Sajjadi: Is a M.sc in clinical biochemistry and lecturer in the department of chemistry and biochemistry in the medical laboratory technology faculty of Khatam Al-Nabieen University. His research interest: effect of medicinal plants on cancer prevention and treatment, diabetes and memory.

- Sayed Yousof Mousavi: Is a Ph.D. of medical physiology and Professor in the Faculty of Medical Sciences, Khatam Al-Nabieen University. $\mathrm{He}$ is positioned as vice-chancellor of research and technology head of Research and Technology Center of Khatam Al-Nabieen University. He has experience in the area of Brain cannulation in rats, Brain slices, Whole-cell patch-clamp recording methods, Extra- and intracellular recording methods, Methods of learning and memory studies, Methods of the animal model of addiction. His research interest: Network Physiology, Synaptic plasticity and Metaplasticity.

Cite this article: Akbari E, Alami K, Hossaini D, Nazari ML, Salehi MH, Sajjadi M, et al. Effect of Afghan Saffron (Crocus sativus L.) Aqueous Extract on Withdrawal Signs in Morphine-Dependent Rats. Pharmacogn J. 2020;12(6)Suppl:1727-31. 